\title{
Correlation between Au Lithogeochemical Anomalies and Fault-density using Geostatistical and Fractal Modeling in Sharafabad-Hizehjan Area, NW Iran
}

\author{
Rezvan Rassi ${ }^{1, *}$, Peyman Afzal ${ }^{1,2}$ \\ ${ }^{1}$ Department of Mining Engineering, South Tehran Branch, Islamic Azad University, Iran \\ ${ }^{2}$ Camborne School of Mines, University of Exeter, UK
}

Copyright $(\underset{0}{2015}$ Horizon Research Publishing All rights reserved.

\begin{abstract}
The aim this study is to examine the correlation between $\mathrm{Au}$ lithogeochemical anomalies and density of faults utilizing geostatistical analysis, Concentration-Number (C-N) and Concentration-Area (C-A) fractal models in Hizehjan-SharafAbad area, NW Iran. This area is located in the Alborz-Azerbayjan structural zone and Arasbaran metallogenic belt having an Au epithermal type mineralization. In this study, Au variograms, anisotropic ellipse of Au distribution and rose diagram of fault trends were constructed whose analyses showed good correlation between major axis of ellipse with main trend of faults. Consequently, the C-N and C-A log-log plots were constructed for $\mathrm{Au}$ and fault-density distributions which revealed very good correspondence/correlation. The results obtained by fractal models indicate a strong correlation between main $\mathrm{Au}$ anomalies, anisotropic ellipse major axis and fault-density distributions.
\end{abstract}

Keywords Geostatistical Modeling, Au Epithermal Type, Fractal Modeling, Concentration-Number (C-N), Concentration-Area (C-A), Hizehjan-SharafAbad

\section{Introduction}

A geochemical anomaly occurs by various natural processes related to different geological and mineralization events [1-4]. It may reveal important changes either in geological characteristics and/or mineralization processes.
Several methods are used for geochemical data interpretation and modeling such as classical statistics [5-7], geostatistical and fractal/multifractal modeling [8-13]. Fractal theory has been established by Mandelbrot [16] as an important non-Euclidean branch in mathematical sciences. Several models have been proposed and developed based on fractal geometry for application in the geosciences since the 1980s [17-26]. The purpose this study is to examine the correlation between $\mathrm{Au}$ geochemical anomalies and faults using geostatistical, Concentration-Number (C-N) and Concentration-Area (C-A) fractal modeling in the Hizehjan-SharafAbad, NW Iran.

\section{Geological Setting}

This area, situated in East Azbeyjan province, was selected for study of epithermal $\mathrm{Au}$ mineralizations occurring in Alborz-Azerbayjan structural zone and Arasbaran (Ahar) metallogenic belt (Fig. 1). There are three types of lithological units in this area as follows:

1- Upper Eocene pyroclastic rocks especially tuffs and lava.

2- Mio-Pliocene pyroclastic rocks and acidic domes and dykes specifically andesitic and dacitic rocks.

3- Quaternary alluvial units.

The main alteration zones include advanced and medium argillic, propylitic and silicification in this area. Furthermore, andesitic and dacitic dykes cut the older rocks. 
Legend

\section{---- Concealed fault}

- Major fant

Andesitic dykes

Dacitic dykes

Micro-quartzm onzodiorite dykes

Argillic zone

--_- Propylitic zone

Silicified zone

Acidic tuff

Channel fill deposits

Trachyandesit to dacitic andesite lava and acidic tuff

Trachyt to trachyandesit flow and dome

費 Village-Hizeh Jan

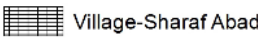
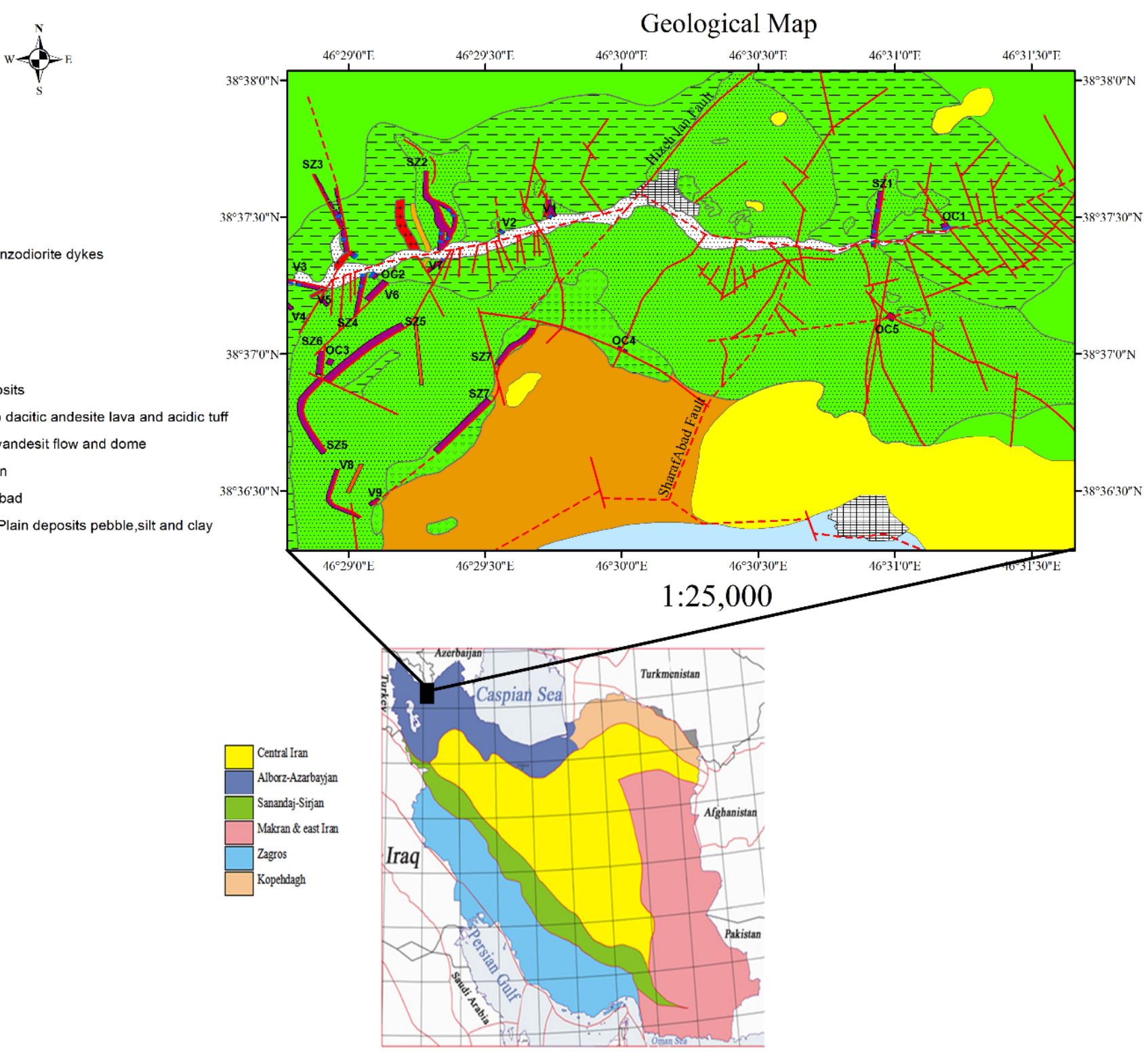

Figure 1. Geological map of the studied area and its position in the Alborz-Azerbayjan zone 


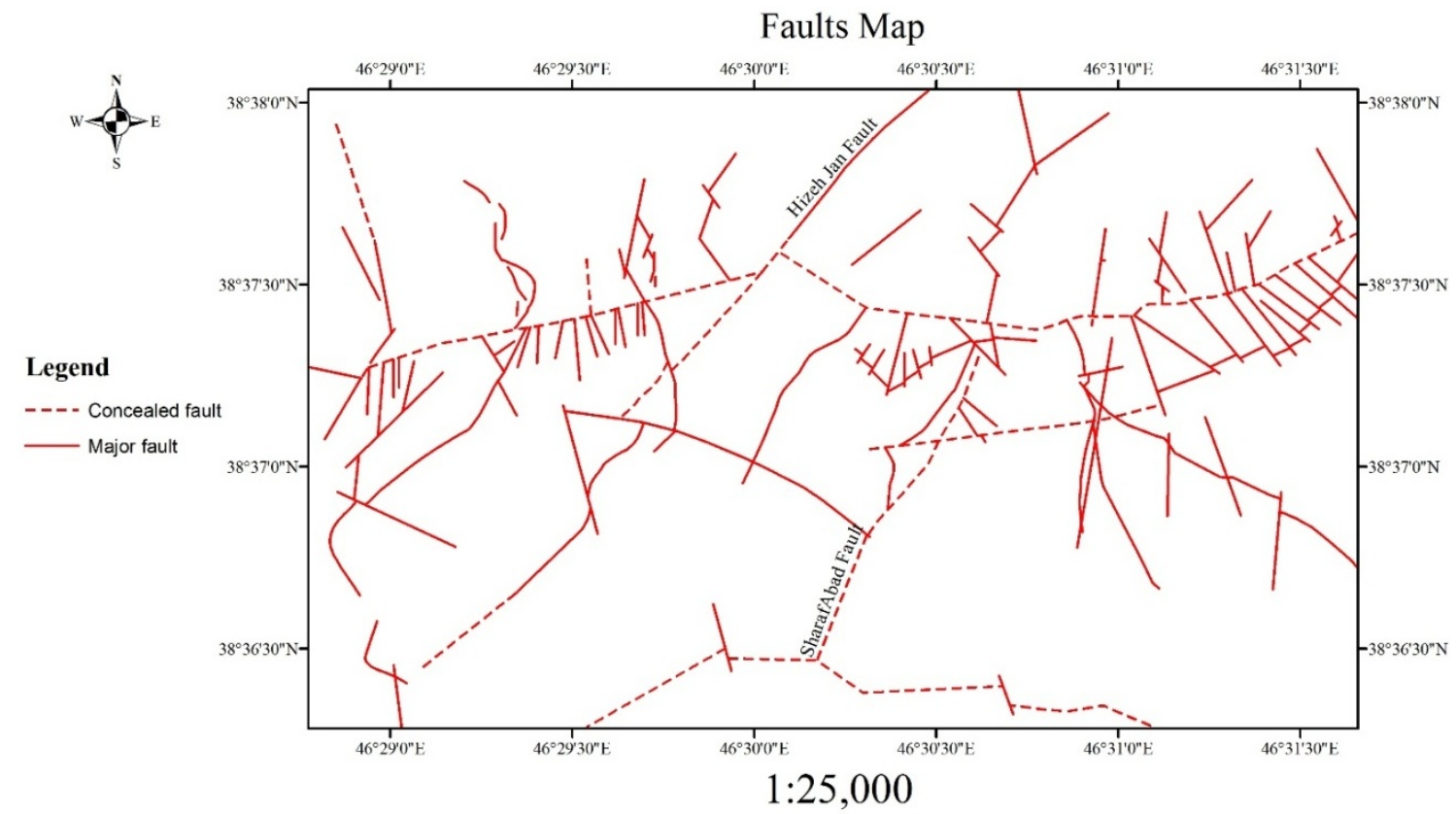

\section{Faults' rose diagram}

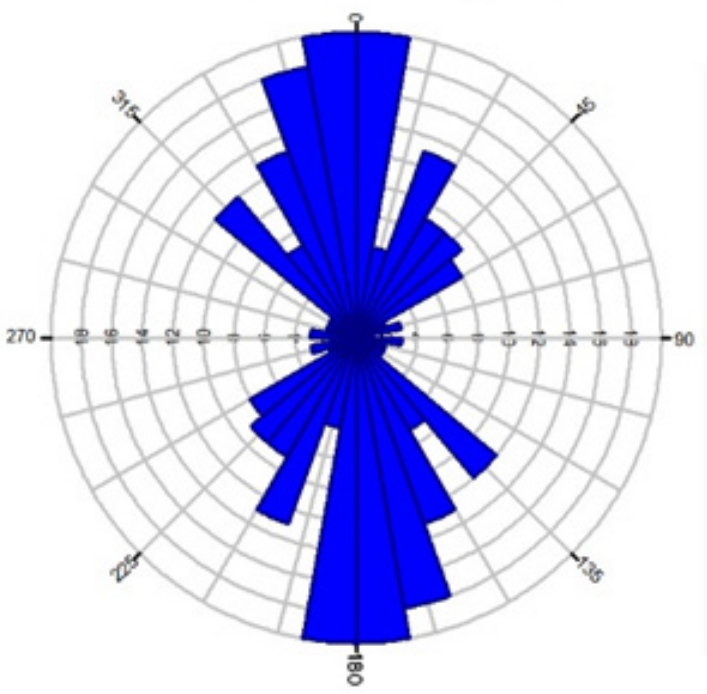

Figure 2. Faults' map and rose diagram of the studied area

\section{Tectonic Setting}

The main structure in the Arasbaran metallogeny region been achieved as a result of the Alpine orogeny especially Late Cretaceous Laramid phase. The major trend of its fault systems is NNE-SSW. There are two main faults including Hizehjan and SharafAbad faults in this area, as depicted in Fig. 2.

\section{Methodology}

\subsection{Concentration-Area (C-A) fractal model}

Cheng et al.[8] proposed an elemental concentration-area (C-A) fractal model, which was used to describe the geochemical background and anomalies. This model will also serve to illustrate the relationship between the obtained results with the geological, geochemical and mineralogical information. Its most powerful features are easy implementation and the ability to compute quantitative anomalous thresholds [12],[20]. This model was expressed as follows:

$$
A(\rho \leq v) \infty \rho^{-a 1} ; A(\rho \geq v) \infty \rho^{-a 2}
$$

where $A(\rho)$ denotes the area with concentration values greater than the contour value $\rho$; $v$ represents the threshold; and $\mathrm{a}_{1}$ and $\mathrm{a}_{2}$ are characteristic exponents. Using fractal theory, Cheng et al.[8] derived similar power-law relationships and equations in extended form Cheng et al.[8] 


\subsection{Concentration-Number (C-N) Fractal Model}

The Number-Size (N-S) fractal model, which was proposed by Mandelbrot [16], can be utilized to defined the distribution of geochemical populations without pre-processing of data. Based on that model, the $(\mathrm{C}-\mathrm{N})$ fractal model was proposed by Hasanpour and Afzal [27] for analyzing the raw data of geological models. This model displays relations between geological attributes (e.g., ore elements in this paper) and their cumulative frequency of samples. The model is expressed by the following formula [16],[25],[28-29]:

$$
\mathrm{N}(\geq \rho) \propto \mathrm{F} \rho^{-\mathrm{D}}
$$

where $\rho$ indicates element concentration, $N(\geq \rho)$ shows cumulative number of samples with concentration values greater than or equal to $\rho, F$ is a constant and $\mathrm{D}$ is the scaling exponent or fractal dimension of the distribution of element concentrations. According to Mandelbrot (1983) and Deng et al.[28], log-log plots of $N(\geq \rho)$ versus $\rho$ reveal straight line segments with different slopes, -D values, corresponding to different intervals. This method is based on the fact that the number of samples reduce with increasing concentrations.

\section{Discussion and Results}

Geostatistical modeling including variography and generation of anisotropic ellipsoid was carried out based on 181 lithogeochemical samples by RockWorks software package. Main directions in the anisotropic ellipsoid are N176 and N86 for highest and lowest ranges respectively (Fig. 3). Comparison between anisotropic ellipse of variograms and rose diagram of fault trends denotes that there is a good correlation between extension of $\mathrm{Au}$ mineralization and main faults in this area, as depicted in Fig. 3.

Moreover, the C-N log-log plot was created for Au which shows five $\mathrm{Au}$ geochemical populations. First threshold is $0.012 \mathrm{ppm}$ and extremely anomalies commenced from 1.6 ppm which located in the four samples in the eastern and western parts of the area (Fig. 4). Furthermore, distribution of density of faults was generated by ArcGIS and RockWorks softwares, as depicted in Fig. 5. It was built up based on intersection of faults, length of faults and density of faults in different cells due to Au mineralization type. The density of faults was classified by the (C-A) fractal modeling which was indicated five populations in this area as illustrated in Fig. 6. High and extremely high parts of fault density distribution have threshold values of 12.6 and 25.1, respectively.

Comparison between high density values and $\mathrm{Au}$ extremely anomalies reveals that there is a good correlation between $\mathrm{Au}$ mineralization and fault density distribution, as is obvious in the western and eastern parts of this area. As a result, the main Au mineralizations and anomalies occurred along the intersections of faults.

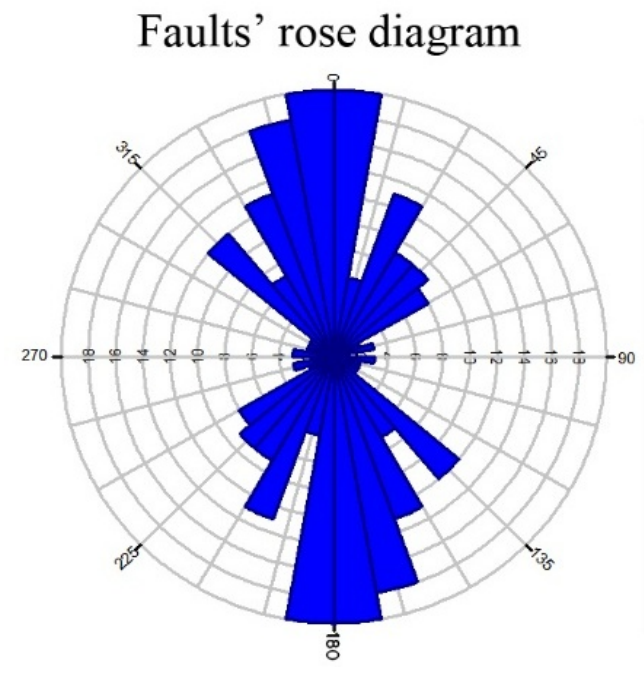

$$
\begin{array}{ll}
\text { Exponential With } & \text { Nugget } \\
\text { Correlation } & 0.98 \\
\text { Anisotropy Ratio } & 0.65 \\
\text { Nugget } & 0.001 \\
\text { Relative Sill } & 0.052 \\
\text { Major Axis Direction } 176.2 \\
\text { Minor Axis Direction } 86.2 \\
\text { Major Axis Range } & 482.674 \\
\text { Minor Axis Range } & 312.977
\end{array}
$$

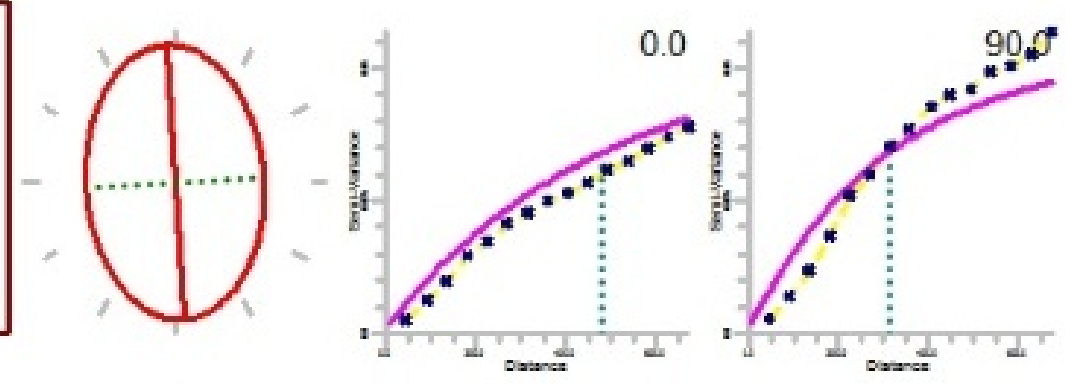

Figure 3. Variograms of $\mathrm{Au}$ and anisotropic ellipsoid within rose diagram 

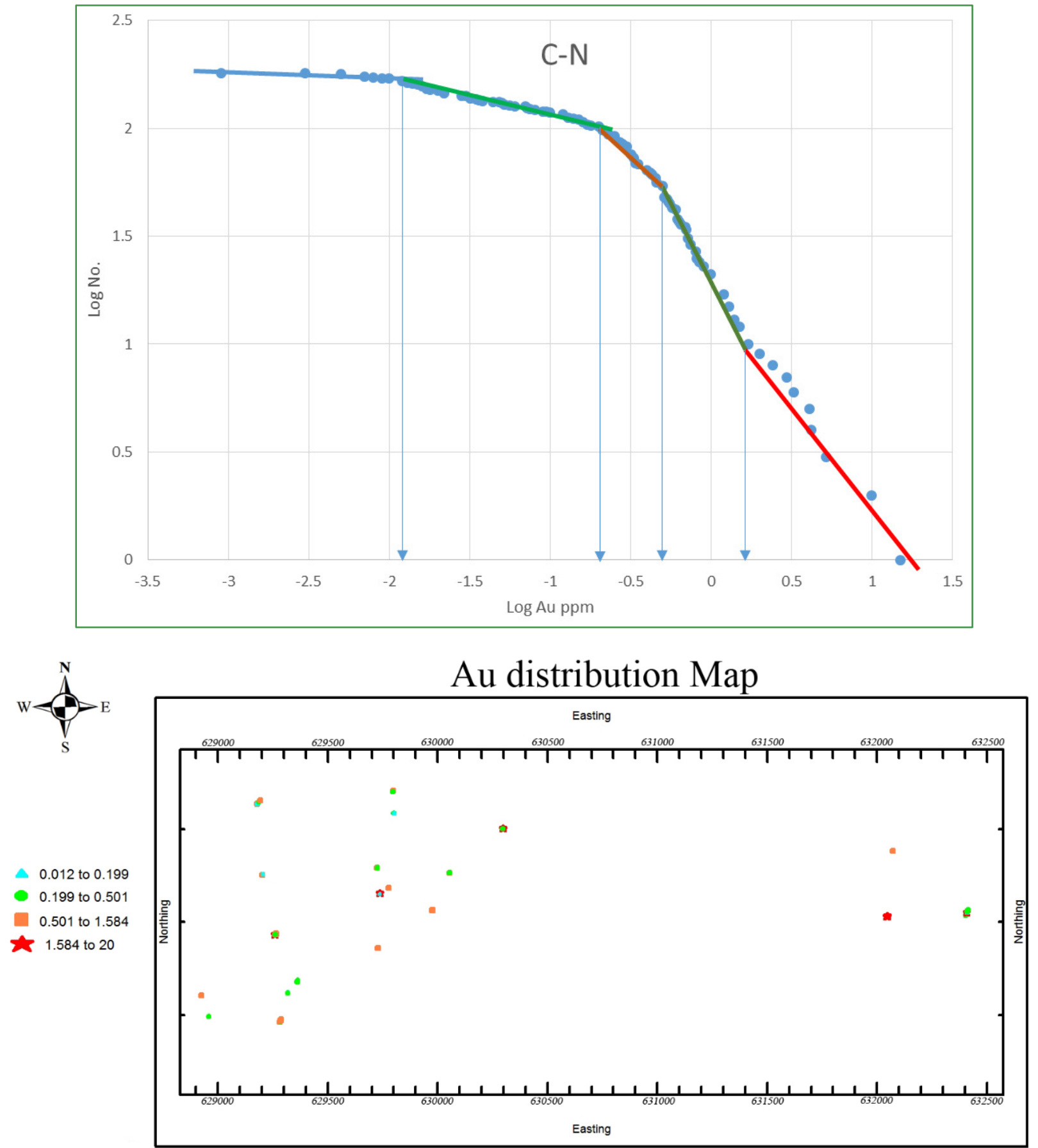

Figure 4. C-N log-log plots and Au distribution in this area 


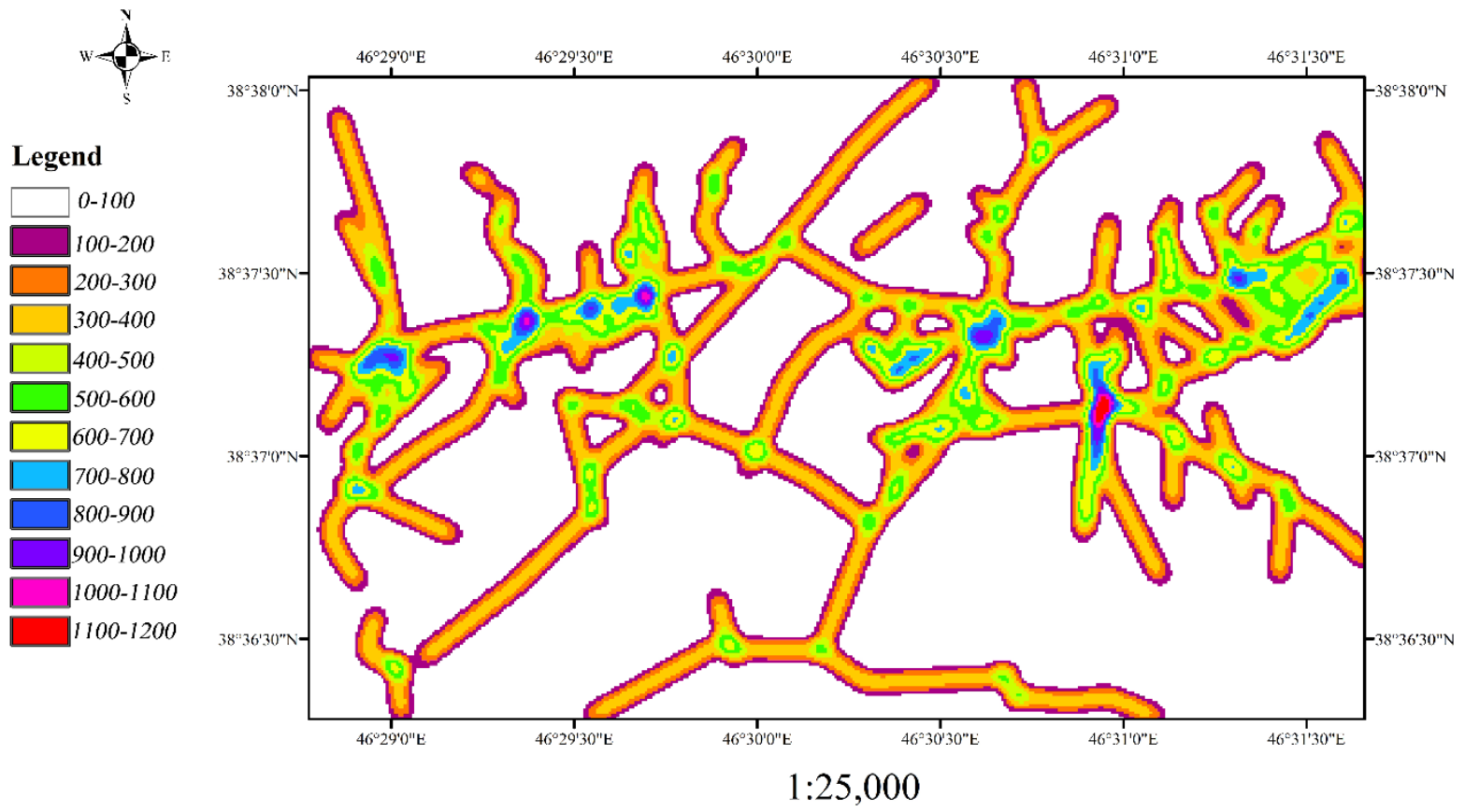

Figure 5. Faults' density distribution map

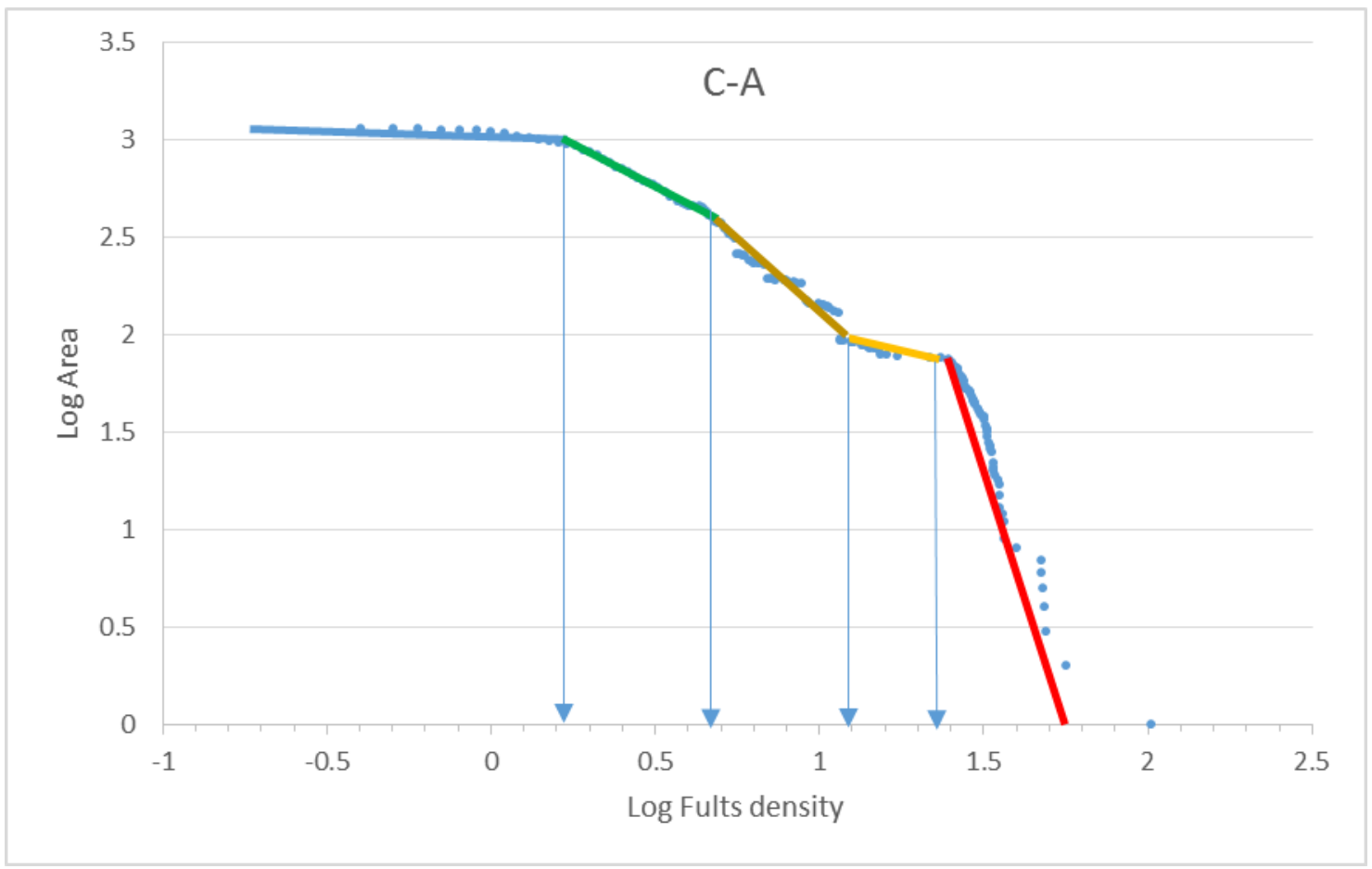




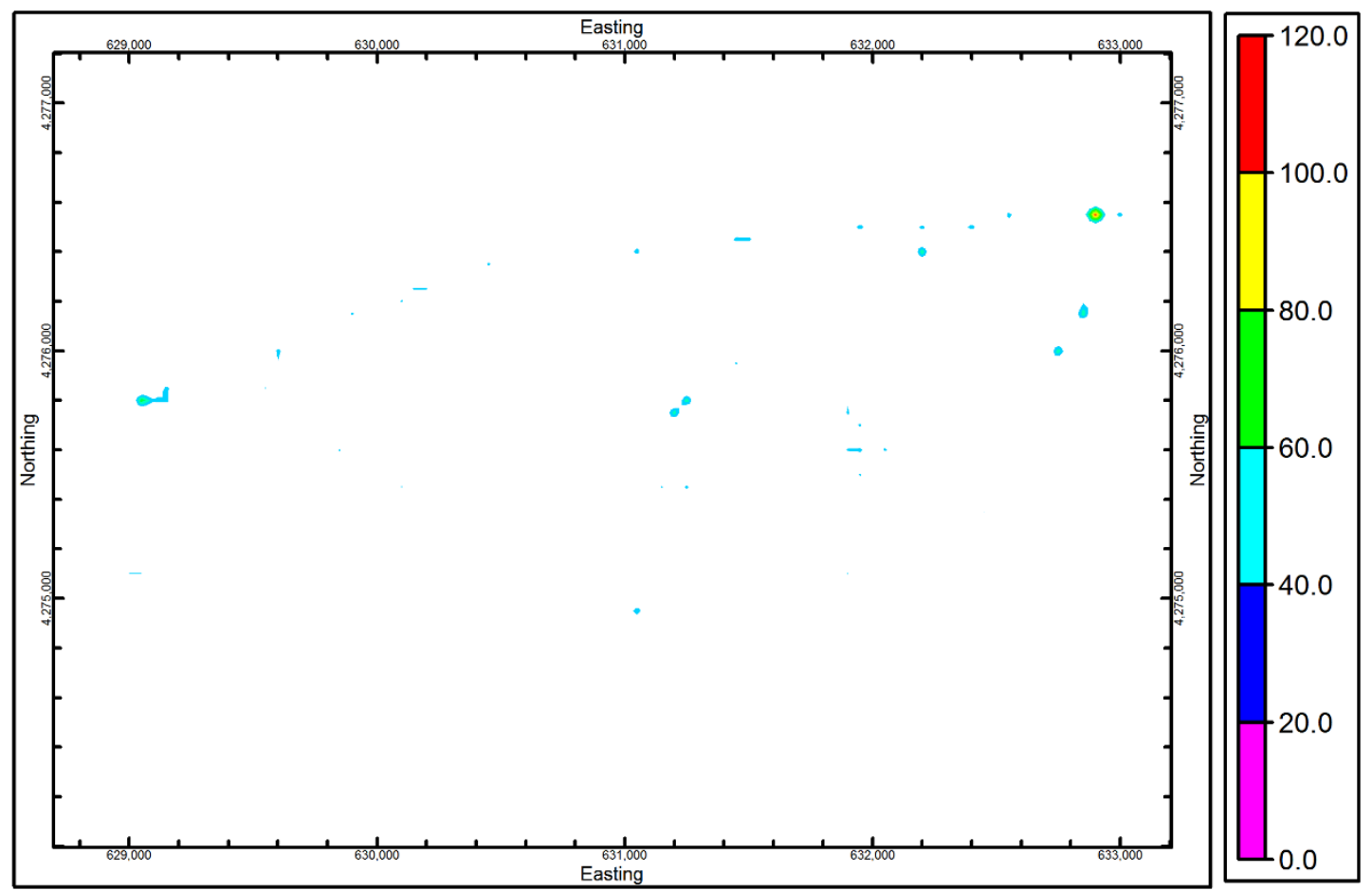

Figure 6. C-A log-log plot and distribution map for fault density in the studied area

\section{Conclusions}

Geostatistical and fractal modeling show that a direct relationship between Au mineralization and faults. The main $\mathrm{Au}$ anomalies with Au higher than $0.5 \mathrm{ppm}$ occurred in the faults' intersections. The main directions for faults and $\mathrm{Au}$ mineralization is similar based on rose diagram, anisotropic ellipsoid and variography which reveal that the main direction for faults is high values of length in the anisotropic ellipsoid. Moreover, results obtained by the geostatistical and fractal modeling show that there is main Au prospects in the eastern and western parts of the area.

\section{Acknowledgements}

The authors would like to thank Mr. Behzad Mohammadi in Geological Survey of Iran (G.S.I) for authorizing the use of exploration data.

\section{REFERENCES}

[1] Zhao P., Theory and practice of geo anomaly in mineral exploration. 1st Ed. China Univ. Geosci. Press, Wuhan, China, 1-150(in Chinese with English abstract), 1999.

[2] Cheng Q., Mapping singularities with stream sediment geochemical data for prediction of undiscovered mineral deposits in Gejiu, Yunnan Province, China. Ore Geol. Rev. 32, 314-324, 2007.

[3] Cheng Q. \& Agterberg F.P., Singularity analysis of ore-mineral and toxic trace elements in stream sediments.
Comp. \& Geosci. 35, 234-244, 2009.

[4] Wang W., Zhao J., Cheng Q. \& Liu J., Tectonic-geochemical exploration modeling for characterizing geo-anomalies in southeastern Yunnan district, China. J. Geochem. Explor. 122, 71-80, 2012.

[5] Tukey J.W., Exploratory data analysis. First Ed. Pearson, $1-688,1977$.

[6] Hawkes R.A.W. \& Webb H.E., Geochemistry in mineral exploration. 2nd Ed. Acad. Press, New York, 657, 1979.

[7] Reimann C., Filzmoser P. \& Garrett R.G., Background and threshold: critical comparison of methods of determination. Sci. Total Environ. 346, 1-16, 2005.

[8] Cheng Q., Agterberg F.P. \& Ballantyne S.B., The separation of geochemical anomalies from background by fractal methods. J. Geochem. Explor. 51, 109-130, 1994.

[9] Agterberg F.P., Cheng Q., Brown A., Good D., Multifractal modeling of fractures in the Lac du Bonnet Batholith, Manitoba. Comput. Geosci. 22, 5, 497-507, 1996.

[10] Li C., Ma T. \& Shi J., Application of a fractal method relating concentrations and distances for separation of geochemical anomalies from background. J. Geochem. Explor. 77, 167-175, 2003.

[11] Zuo R., Cheng Q. \& Xia Q., Application of fractal models to characterization of vertical distribution of geochemical element concentration. J. Geochem. Explor. 102, 1, 37-43, 2009.

[12] Afzal P., Khakzad A., Moarefvand P., Rashidnejad Omran N., Esfandiari B. \& Fadakar A.Y., Geochemical anomaly separation by multifractal modeling in Kahang (Gor Gor) porphyry system, Central Iran. J. Geochem. Explor. 104, 34-46, 2010. 
[13] Afzal P., Alhoseini S. H., Tokhmechi B., Ahangaran D. K., Yasrebi A. B., Madani N., Wetherelt A., Outlining of high quality coking coal by concentration-volume fractal model and turning bands simulation in East-Parvadeh coal deposit, Central Iran. J . Coal Geology. Explor. 127, 88-89, 2014.

[14] Heidari M., Ghaderi M., Afzal P., Delineating mineralized phases based on lithogeochemical data using multifractal model in Touzlar epithermal $\mathrm{Au}-\mathrm{Ag}(\mathrm{Cu})$ deposit, NW Iran. Applied Geochemistry 31, 119-132, 2013.

[15] Soltani, F., Afzal, P., Asghari, O., Delineation of alteration zones based on sequential Gaussian simulation and concentration-volume fractal modeling in the hypogene zone of Sungun copper deposit, NW Iran. J. Geochem. Explor. http://dx.doi.org/10. 1016/j.gexplo.2014.02.007, 2014.

[16] Mandelbrot B.B., The fractal geometry of nature. Freeman, San Fransisco, 1-468, 1983.

[17] Agterberg F.P., Cheng Q. \& Wright D.F., Fractal modeling of mineral deposits. In: Elbrond J. \& Tang X. (Eds.): 24th APCOM Sym. Proc., Montreal, Canada, 43-53, 1993.

[18] Sanderson D.J., Roberts S. \& Gumiel P, A fractal relationship between vein thickness and gold grade in drill core from La Codosera, Spain. Econ. Geol. 89, 168-173, 1994.

[19] Turcotte D.L., Fractals in petrology. Lithos 65, 261-271, 2002.

[20] Gonçalves M.A., Mateus A. \& Oliveira V., Geochemical anomaly separation by multifractal modeling. J. Geochem. Explor. 72, 91-114, 2001.

[21] Monecke T., Monecke J., Herzig P.M., Gemmell J.B. \& Monch W., Truncated fractal frequency distribution of element abundance data: a dynamic model for the metasomatic enrichment of base and precious metals. Earth Planet. Sci. Lett. 232, 363-378, 2005.

[22] Gumiel P., Sanderson D.J., Arias M., Roberts S. \&
Martin-Izard A., Analysis of the fractal clustering of ore deposits in the Spanish Iberian Pyrite Belt. Ore Geol. Rev. 38, 307-318, 2010 .

[23] Afzal P., Fadakar A.Y., Khakzad A., Moarefvand P. \& Rashidnejad Omran N., Delineation of mineralization zones in porphyry $\mathrm{Cu}$ deposits by fractal concentration-volume modeling. J. Geochem. Explor. 108, 220-232, 2011.

[24] Zuo R., Identifying geochemical anomalies associated with $\mathrm{Cu}$ and $\mathrm{Pb}-\mathrm{Zn}$ skarn mineralization using principal component analysis and spectrum-area fractal modeling in the Gangdese Belt, Tibet (China). J. Geochem. Explor. 111, 13-22, 2011.

[25] Sadeghi B., Moarefvand P., Afzal P., Yasrebi A.B. \& Daneshvar Saein L., Application of fractal models to outline mineralized zones in the Zaghia iron ore deposit, Central Iran. J. Geochem. Explor. 122, 9-19, 2012.

[26] Yasrebi A.B., Afzal P., Wetherelt A., Foster P. \& Esfahanipour R., Correlation between geology and concentration-volume fractal models: significance for $\mathrm{Cu}$ and Mo mineralized zones separation in the Kahang porphyry deposit (Central Iran). Geol. Carpathica 64, 2, 153-163, 2013.

[27] Afzal P., Hassanpour Sh., Application of concentration-number (C-N) multifractal modeling for geochemical anomaly separation in Haftcheshmeh porphyry system, NW Iran. Arab. J. Geophys. Res. 6, 957-970, 2013.

[28] Deng J., Wang Q., Yang L., Wang Y., Gong Q. \& Liu H., Delineation and explanation of geochemical anomalies using fractal models in the Heqing area, Yunnan Province, China. J. Geochem. Explor. 105, 95-105, 2010.

[29] Mohammadi A., Khakzad A., Rashidnejad Omran N., Mahvi MR., Moarefvand P., Afzal P., Application of number-size (N-S) fractal model for separation of mineralized zones in Dareh-Ashki gold deposit, Muteh Complex, Central Iran. Arab J Geosci 6:4387-4398, 2013. 